\title{
The Use of Highly Active Additives for the Production of Clinkerless Binders
}

\author{
Murtazaev S-A.Y.
}

Department of materials science and engineering

Kh. Ibragimov Complex Institute of the Russian Academy of Sciences

Department of technical sciences

Academy of science of the Chechen Republic

Grozny State Petroleum Technical University

named after M.D. Millionschikov

Grozny, Russia

s.murtazaev@mail.ru

Ismailova Z.Kh.

Building faculty

Grozny State Petroleum Technical University named M.D. Millionschikov

Grozny, Russia

ismailova-z-h@mail.ru
Salamanova M.Sh.

Department of materials science and engineering

Kh. Ibragimov Complex Institute of the Russian Academy of Sciences

Building faculty

Grozny State Petroleum Technical University

named after M.D. Millionschikov

Grozny, Russia

madina_salamanova@mail.ru

\section{Khadissov V.Kh.}

Department of materials science and engineering Kh. Ibragimov Complex Institute of the Russian Academy of Sciences

Grozny State Petroleum Technical University named M.D. Millionschikov, Grozny, Russia v.hadisov77@mail.ru

Tulaev Z.A.

Building faculty

Grozny State Petroleum Technical University named M.D. Millionschikov

Grozny, Russia

tulaev_zelim@mail.ru

\begin{abstract}
The relevance of the problem of producing clinkerless binders is well known, since the production of cement on a clinker basis is a very difficult technological process, requiring serious financial expenses. It is also environmentally controversial, due to the fact that the burning process releases a huge amount of carbon dioxide into the atmosphere, polluting the environment and causing significant damage to humanity. This article presents the results of research and recipes of binders of alkaline activation. The mechanism for the formation of the structure and strength of a geopolymer stone is given, which is a consequence of complex physicochemical processes.
\end{abstract}

Keywords-binders of alkaline activation, aluminosilicate skeleton, hydrogel, portland cement clinker, siliceous caliche, highly-active materials, metakaolin, mechanical activation

\section{INTRODUCTION}

Portland cement is a leading "constructional" material used in the production of a wide variety of construction products. According to some statistical data [1, 4], the volume of its production up to 2020 can reach approximately 90 million tons per year. Nevertheless, it is necessary to note that the production of Portland cement is cost-intensive in terms of material and energy. It is known $[1,6]$ that in order to get 1 ton of this binder one consumes almost two times more non- reproducible natural raw materials. Burning process of about 1 ton of Portland cement clinker consumes about $190 \mathrm{~kg}$ of standard fuel and $120 \mathrm{kWh} / \mathrm{t}$ of electricity. Moreover, when burning 1 ton of clinker, $450 \mathrm{~kg}$ of carbon dioxide is emitted into the atmosphere, and this is a serious environmental problem of global level.

Absolutely, there exist other binders that make it possible to refuse such an expensive material, for example, lime-silica and gypsum compositions, but the usage, in the first case, of autoclave treatment is associated with maintaining high pressures $(0.9-1.3 \mathrm{MPa})$ and temperatures $\left(168-198{ }^{\circ} \mathrm{C}\right)$. It increases the cost and complexity of the technology. And the production of gypsum, in the second case, gives the product relatively cheap, but does not have the necessary mechanical and operational parameters.

The analysis of the data $[2,3,5,8]$ shows the need to develop an environmentally friendly and inexpensive binder, for partial replacement of Portland cement, at least in areas of construction that do not require high technical and functional properties. Therefore, the development of recipes and the study of the properties of clinkerless binders on a liquid glass binder and concretes based on them is a promising direction for the development of construction industry. 
Liquid glass is produced in almost all countries of the world. It is famous for its low cost and availability of raw materials and is used in many industries. The greatest preference is given to sodium liquid glass, since it has high astringent properties and is capable of forming a strong conglomerate during solidification $[9,10]$.

Sodium liquid glass is a complex nano-dispersed system of sodium silicates with a ratio of $\mathrm{Si}_{2} \mathrm{O} / \mathrm{Na}_{2} \mathrm{O}=1-4$. There are three binary compounds of this system: sodium orthosilicate $2 \mathrm{Na}_{2} \mathrm{O} \cdot \mathrm{Si}_{2} \mathrm{O}$, metasilicate $\mathrm{Na}_{2} \mathrm{O} \cdot \mathrm{Si}_{2} \mathrm{O}$ and sodium disilicate $\mathrm{Na} 2 \mathrm{O} \cdot 2 \mathrm{Si} 2 \mathrm{O}[2,3,7]$.

Possessing a number of valuable properties, the products based on sodium liquid glass are characterized by inability to bulk hardening and low water resistance [5]. In order to eliminate these drawbacks, we have modified the liquid glass by highly dispersed mineral powders of natural origin, which will make it possible to obtain a more effective binder and concrete based on them.

\section{METHODS AND MATERIALS}

The natural resource potential of the North Caucasus has enormous reserves of natural raw materials for the production of clinkerless binders, as in mountainous areas there are concentrated reserves of various varieties of caliches, shell limestone, dolomite, large deposits of small quartz sand, limestone, sandstone, large deposits of gypsum stone [1, 6]. For the implementation of the research, prepared mineral powders from rocks of different origin were used:

- quartz sand;

- waste stone grinding of limestone;

- volcanic tuff;

- silicified marl.

\section{RESULTS}

The energy dispersive microanalysis of the powders studied using a Quanta 3D 200 i scanning electron microscope showed a significant difference in chemical composition of natural additives (Table 1).

TABLE I. CHEMICAL COMPOSITION OF HIGH-DISPERSE POWDERS, $\%$

\begin{tabular}{|c|c|c|c|c|c|c|c|c|c|}
\hline Item & $\mathbf{M g O}$ & $\mathbf{A l}_{2} \mathbf{O}_{3}$ & $\mathbf{S i O}_{2}$ & $\mathbf{K}_{2} \mathbf{O}$ & $\mathbf{C a O}$ & $\mathbf{F e}_{2} \mathbf{O}_{3}$ & $\mathbf{T i O}_{2}$ & $\mathbf{S O}_{3}$ & $\mathbf{p p p}$ \\
\hline Quartz sand & 6.32 & 14.99 & 73.83 & 1.83 & 0.60 & 0.97 & 1.32 & 0.14 & - \\
\hline Volcanic tuff & 0.20 & 13.57 & 73.67 & 6.00 & 1.79 & 1.52 & 2.85 & - & 0.40 \\
\hline Limestone meal & 0.72 & 1.55 & 5.05 & 0.60 & 90.14 & 1.40 & - & 0.49 & - \\
\hline Siliceous caliche & 1.64 & 6.42 & 28.6 & 1.33 & 16.9 & 1.08 & 0.47 & 0.29 & 43.2 \\
\hline
\end{tabular}

Volcanic tuff and quartz sand are distinguished by higher silica content, siliceous caliche is characterized by more uniform silica and calcium oxide content, and calcium oxide is predominant in limestone. The obtained chemical analysis made it possible to predict the properties of the proposed clikerless binders on the basis of the studied powders.

Before the preparation of highly dispersed powders from the studied rocks, they were pre-ground in a jaw crusher, and then subjected to fine grinding for $1 \mathrm{~h}$ in mills of various designs:

- Roller mill LMR-15;

- Vibration ball mill VM-20.

At certain intervals, the samples were taken from the mills in order to determine the specific surface of powders and conduct a comparative analysis (using the PSK-12 instrument) $[6,7]$.

The crushed siliceous caliche was subjected to heat treatment in a muffle roaster at the temperature of $700{ }^{\circ} \mathrm{C}$, and after heat treatment it was again crushed for $3 \mathrm{~min}$ to activate the surface. As studies have shown (Figure $1 \mathrm{a}, \mathrm{b}$ ), the technological factor significantly affects the activation process of mineral additives.

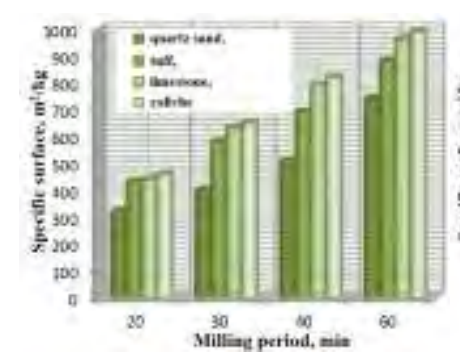

(a)

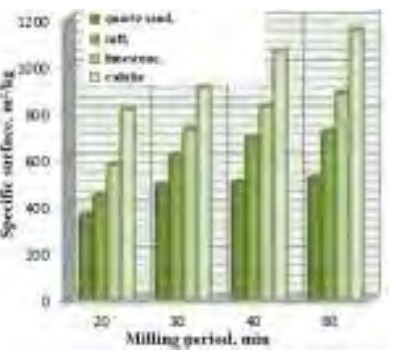

(b)
Fig. 1. The dependence of the quantity of mineral powders specific surface on the activation in roller mill (a) and vibration ball mill (b).

The grinding in a vibratory ball mill gives a fairly high result on the specific surface in almost all sampling intervals. It can be noted that with a further increase in the duration of grinding, it is vibroactivation that can increase the specific surface of the ground particles of mineral additives.

It is necessary to note that in a roller mill with an increase in the duration of crashing more than $1 \mathrm{~h}$, the specific surface of the powders did not change, which can be explained by the features of the grinding unit.

The mineral additive from quartz sand is crushed worse than all materials, which indicates the increased hardness of rock-forming sand minerals. For volcanic tuff, a higher grindability can be explained by the content of quartz of green schist degree of metamorphism with a defective structure.

The best indicators of grindability among the studied additives were limestone and siliceous caliche. At the same time their specific surface was at the level of $990-1150 \mathrm{~m}^{2} / \mathrm{kg}$. Such high grindability is reasoned by the organic-chemical oolitic genesis of minerals in the form of aggregates of spherical or ellipsoidal oolites of calcite, a small amount of quartz and dolomite, cemented by a cryptocrystalline carbonate substance, because of their softness, they are grinded thinner than other mineral additives and clinker.

At the next stage, the number of Bronsted active crystallization centers on the surface of mineral powder was investigated by the method [8] of the determination of the exchange capacity with respect to calcium ions.

Table 2 shows the results of tests conducted in order to determine the number of active crystallization centers, which 
showed that the surface concentration of ion-exchange centers of mineral powders varies unevenly and does not depend on the degree of grinding.

TABLE II. THE SURFACE ACTIVITY OF MINERAL POWDERS

\begin{tabular}{|c|c|c|c|c|}
\hline Mineral powder & $\begin{array}{c}\text { Activity } \\
\text { coefficient } \\
\boldsymbol{C}_{\boldsymbol{a}}, \boldsymbol{\%}\end{array}$ & $\begin{array}{c}\text { Hydraulic } \\
\text { activity } \\
\text { coefficient }\end{array}$ & $\begin{array}{c}\text { Number of } \\
\text { active } \\
\text { crystallization } \\
\text { centers, } \\
\mathbf{m g} \cdot \mathbf{e c v} / \mathbf{g}\end{array}$ & $\begin{array}{c}\text { Specific } \\
\text { surface of } \\
\text { powders, } \\
\mathbf{m}^{\mathbf{2}} \mathbf{k g}\end{array}$ \\
\hline Quartz sand & 22 & 1.76 & 21 & 810 \\
\hline Volcanic tuff & 37 & 1.90 & 34 & 905 \\
\hline Limestone & 8 & 1.24 & 12 & 1060 \\
\hline Caliche $\left(700^{\circ} \mathrm{C}\right)$ & 62 & 2.03 & 42 & 1150 \\
\hline
\end{tabular}

It should be noted that mineral powders based on volcanic tuff and siliceous caliche, roasted at $700{ }^{\circ} \mathrm{C}$, are the most active. This can be explained by the presence on the mineral surface of highly dispersed powders of a large number of exchange sites, a significant part of which are acids and bases according to Bronsted classification $[1,7]$.

Thus, analyzing the obtained results, it can be stated that the activity coefficients, including the number of active crystallization centers, largely depend on the degree of disclosure of defects formed during their grinding. Together all these facts contribute to the increase in the reactivity of studied powders used in concrete as highly dispersed additives.

After the confirmation of the reactivity of the proposed powders, test beams with dimensions of $20 \times 20 \times 100 \mathrm{~mm}$ were prepared out of the following compound: highly dispersed component, Volsky quartz sand (added in a 1:3 ratio), sodium fluosilicate, liquid sodium glass with a silicate module of 2.8 and density of $1.24 \mathrm{~g} / \mathrm{sm}^{3}$, sodium hydroxide. The prepared beams were hardened under normal conditions at the temperature of $20 \pm 2{ }^{\circ} \mathrm{C}$, but after 2 days some of the twin beams were placed in a drying oven at the temperature of 40 ${ }^{\circ} \mathrm{C}$ for several days. The recipes and properties of clinkerless binders are shown in Table 3 and Figure 2.

TABLE III. THE RECIPES AND PROPERTIES OF ALKALINE ACTIVATION BINDERS

\begin{tabular}{|c|c|c|c|c|c|c|c|c|}
\hline \multirow{2}{*}{ 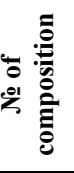 } & \multicolumn{7}{|c|}{$\begin{array}{c}\text { The components of alkaline activation } \\
\text { binders, } \%\end{array}$} & \multirow{2}{*}{$\begin{array}{c}\text { The activity } \\
\text { MPa in } 28 \text { days } \\
\text { of natural } \\
\text { hardening }\end{array}$} \\
\hline & $Q S$ & $T C$ & $V T$ & $L M$ & 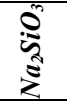 & 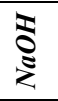 & $\begin{array}{l}0 \\
\text { है } \\
\text { है }\end{array}$ & \\
\hline 1 & 80 & - & - & - & 12.0 & 1.0 & $\begin{array}{l}7.0 \\
\end{array}$ & 22.3 \\
\hline 2 & - & 80 & - & - & 12.0 & 1.1 & 6.9 & 42.1 \\
\hline 3 & - & - & 80 & - & 14.0 & 1.0 & 5.0 & 37.6 \\
\hline 4 & - & - & - & 80 & 10.0 & 0.6 & 9.4 & 16.5 \\
\hline 5 & 80 & - & - & - & 14.0 & - & 6.0 & 20.3 \\
\hline 6 & - & 80 & - & - & 14.1 & - & 5.9 & 39.2 \\
\hline 7 & - & - & 80 & - & 16.0 & - & 4.0 & 33.1 \\
\hline 8 & - & - & - & 80 & 11.6 & - & 8.4 & 13.7 \\
\hline
\end{tabular}

The test results of the investigated compositions based on alkaline activation binders, presented in Table 3 , showed quite high strength results for the beams using powders from thermo-activated caliche and volcanic tuff, and it was found that with increasing temperature, the strength parameters also increase.

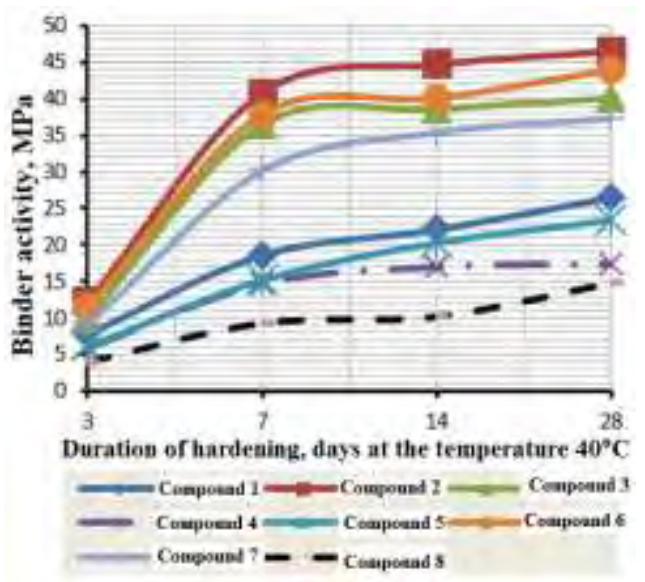

Fig. 2. The dependence clinkerless binder activity on the duration and conditions of hardening.

Also it should be noted that in addition to temperature, the dosage of sodium fluosilicate and the presence of sodium hydroxide affect the activity indicator. Alkaline activation binder with the use of highly dispersed powder of thermally activated caliche showed the best results of $46.5 \mathrm{MPa}$ for hardening at the temperature of $40^{\circ} \mathrm{C}$ and $42.1 \mathrm{MPa}$ for hardening in natural conditions.

In order to study the properties of fine-grained concretes, the cubic beams of $10 \mathrm{sm}$ in size were prepared using a compound of: highly dispersed component (table 3), fractionated sand obtained by mixing in the ratio of $55: 45$ sifting of the Argun deposit and fine sand of the Chervlenskoye deposit. The mixing was carried out with liquid glass, sodium hydroxide and accelerator of the precipitation of silica gel with sodium fluoride in specified proportions.

TABLE IV. THE PROPERTIES OF FINE-GRAINED CONCRETE BASED ON CLINKERLESS BINDERS OF ALKALINE ACTIVATION

\begin{tabular}{|c|c|c|c|c|c|c|c|c|}
\hline \multirow{2}{*}{ 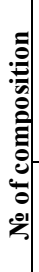 } & \multicolumn{5}{|c|}{ Material consumption $\mathrm{kg}$ per $1 \mathrm{~m}^{3}$} & \multirow{2}{*}{ 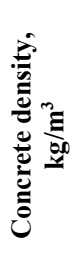 } & \multicolumn{2}{|c|}{$\begin{array}{c}\text { Bending } \\
\text { density, } \\
\text { MPa } \\
\text { at age of } \\
\text { (days). }\end{array}$} \\
\hline & $\begin{array}{l}\text { Highly- } \\
\text { dispersed } \\
\text { powders }\end{array}$ & $\begin{array}{r}\text { Graded } \\
\text { sand }\end{array}$ & 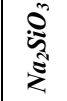 & $\frac{7}{2}$ & $\frac{1}{2}$ & & 7 & 28 \\
\hline 1 & 520 & 1700 & 97.5 & 8.5 & 56.5 & 2240 & 11.8 & 24.7 \\
\hline 2 & 520 & 1700 & 97.5 & 8.5 & 56.5 & 2250 & 31.4 & 45.9 \\
\hline 3 & 520 & 1700 & 97.5 & 8.5 & 56.5 & 2246 & 25.3 & 38.6 \\
\hline 4 & 520 & 1700 & 97.5 & 8.5 & 56.5 & 2235 & 5.9 & 16.7 \\
\hline
\end{tabular}

The prepared beams were hard in normal conditions at the temperature of $20 \pm 2{ }^{\circ} \mathrm{C}$, but after 2 days the beams were placed in a drying oven at the temperature of $40-50{ }^{\circ} \mathrm{C}$ for several days. The test results of the investigated fine-grained concretes based on alkaline activation binders are presented in Table 4.

The alkaline activation binder with the use of highly dispersed powders of thermally activated caliche showed the 
best results, so these beams of concrete were examined on a Quanta 3D 200 i scanning electron microscope with the integrated Genesis Apex 2 EDS microanalysis system from EDAX (Figure 3).
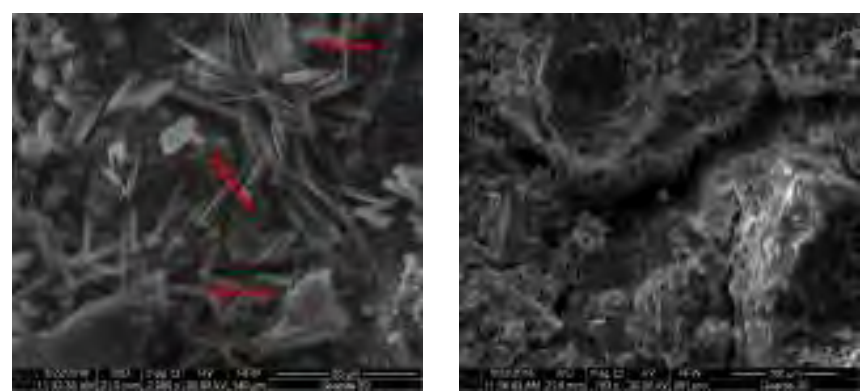

Fig. 3. Micrographs of concrete on thermally activated caliche of alkaline activation.

It was found that in the contact area there is a fairly strong accretion of particles of binder and quartz sand, the surface does not contain defects in the form of growths or cracks, there are irregularities of various shapes and sizes, and the individual particles have a needle-fibrous, vitreous structure (Figure 3), which indicates to the increased activity of a binder.

\section{CONCLUSION}

As the result, the compositions were obtained. The properties of the clinkerless binders on liquid glass binder were studied using highly dispersed mineral components.

It is theoretically stated and practically proved that Brønsted acid centers on the surface of highly active powders accelerate the process of the synthesis of silica gel, promote the polymerization of silicon-oxygen anions, enhance ion exchange reactions and stabilize intergranular contact formation.

The results of the research significantly expand the field of application of clinkerless binders on liquid-glass binder and allow partial replacement of expensive and energy-intensive Portland cement in construction industry.

\section{References}

[1] S.A.Y. Murtazaev, and M.Sh. Salamanova, "Prospects for the use of thermally-activated raw materials of aluminosilicate nature," Privolzhsky Scientific Journal, vol. 46, No 2, pp. 65 -70, 2018.

[2] J. Davidovitz. "Geopolymer," Chemistry and applications. SaintQuentin: Institute Geopolymer, 2008.

[3] P.A. Duxson, and J.L. Fernandez, "Provis Geopolymer technology: The current state of the art," J. Math. Sci., vol. 42, pp.2917-2933, 2007.

[4] E.A. Nikiforov, V.I. Loganina, E.E. Simonov, "Effect of alkaline activation on the structure and properties of diatomite," Vestnik BGTU named after V.G. Shukhov, No 2, pp.30-32, 2008.

[5] V.T. Erofeev, A.D. Bogatov, S.N. Bogatova [etc.], "Bioresistant building composites on the glass wastes," Biosciences Biotechnology Research Asia, vol. 12, No 1, pp. 661-669, 2015.

[6] S.A.Y. Murtazaev, M.Sh. Salamanova, and R.G. Bisultanov, "Highquality modified concretes using a binder based on the reactive active mineral component," Building materials, No 8, pp.74-80, 2016

[7] V.V. Strokova, I.V. Zhernovskiy, and A.V. Maksakov, "Express - a method for determining the activity of silica raw materials for producing granulated nanostructuring aggregate," Construction materials, No 1, pp. $38-39,2013$.

[8] R. Javaherdashti. Microbiologically Influenced Corrosion an Engineering. UK: Insight - Springer-Verlag, 2008.

[9] N.I. Kozhukhova, I.V. Zhernovsky, and M.S. Ocadchaya, "Revisiting a selection of natural and technogenic raw materials for geopolimer binders," International Journal of Applied Engineering Research, vol. 9, No 22, pp. $16945-16955,2014$

[10] N.I. Kozhukhova, I.V. Zhernovsky, and V.V. Strokova, "Evaluational geopolimer binders based on low-calcium fly ash," International Journal of Applied Engineering Research, vol. 10, No 15, pp. 35618-35620, 2015 